\title{
Codominant grasses differ in gene expression under experimental climate extremes in native tallgrass prairie
}

\author{
Ava M Hoffman ${ }^{\text {Corresp., }}{ }^{1,2}$ ， Meghan L Avolio ${ }^{3}$, Alan K Knapp ${ }^{1,2}$, Melinda D Smith ${ }^{1,2}$ \\ 1 Department of Biology, Colorado State University, Fort Collins, Colorado, United States \\ 2 Graduate Degree Program in Ecology, Colorado State University, Fort Collins, Colorado, United States \\ 3 Department of Earth \& Planetary Sciences, The Johns Hopkins University, Baltimore, Maryland, United States \\ Corresponding Author: Ava M Hoffman \\ Email address: ava.hoffman@colostate.edu
}

Extremes in climate, such as heat waves and drought, are expected to become more frequent and intense with forecasted climate change. Plant species will almost certainly differ in their responses to these stressors. We experimentally imposed a heat wave and drought in the tallgrass prairie ecosystem near Manhattan, Kansas, USA to assess transcriptional responses of two ecologically important $\mathrm{C}_{4}$ grass species, Andropogon gerardii and Sorghastrum nutans. Based on previous research, we expected that $S$. nutans would regulate more genes, particularly those related to stress response, under high heat and drought. Across all treatments, $S$. nutans showed greater expression of negative regulatory and catabolism genes while $A$. gerardii upregulated cellular and protein metabolism. As predicted, S. nutans showed greater sensitivity to water stress, particularly with downregulation of non-coding RNAs and upregulation of water stress and catabolism genes. $A$. gerardii was less sensitive to drought, although $A$. gerardii tended to respond with upregulation in response to drought versus $S$. nutans which downregulated more genes under drier conditions. Surprisingly, $A$. gerardii only showed minimal gene expression response to increased temperature, while $S$. nutans showed no response. Gene functional annotation suggested that these two species may respond to stress via different mechanisms. Specifically, A. gerardii tends to maintain molecular function while $S$. nutans prioritizes avoidance. Sorghastrum nutans may strategize abscisic acid response and catabolism to respond rapidly to stress. These results have important implications for success of these two important grass species under a more variable and extreme climate forecast for the future. 


\author{
Codominant grasses differ in gene expression under experimental climate extremes in \\ native tallgrass prairie \\ 3 Ava M. Hoffman ${ }^{1,2}$, Meghan L. Avolio ${ }^{3}$, Alan K. Knapp ${ }^{1,2}$, Melinda D. Smith ${ }^{1,2}$ \\ $4{ }^{1}$ Department of Biology, Colorado State University, Fort Collins, CO, USA. \\ $5{ }^{2}$ Graduate Degree Program in Ecology, Colorado State University, Fort Collins, CO, USA. \\ $6{ }^{3}$ Department of Earth and Planetary Sciences, The Johns Hopkins University, Baltimore, MD, \\ 7 USA. \\ 9 Corresponding Author: \\ 10 Ava Hoffman ${ }^{1,2}$ \\ 12 Email address: ava.hoffman@colostate.edu or avamariehoffman@gmail.com
}

8

11 


\begin{abstract}
14 Abstract
15 Extremes in climate, such as heat waves and drought, are expected to become more frequent and 16 intense with forecasted climate change. Plant species will almost certainly differ in their 17 responses to these stressors. We experimentally imposed a heat wave and drought in the tallgrass 18 prairie ecosystem near Manhattan, Kansas, USA to assess transcriptional responses of two 19 ecologically important $\mathrm{C}_{4}$ grass species, Andropogon gerardii and Sorghastrum nutans. Based on previous research, we expected that $S$. nutans would regulate more genes, particularly those related to stress response, under high heat and drought. Across all treatments, S. nutans showed greater expression of negative regulatory and catabolism genes while $A$. gerardii upregulated cellular and protein metabolism. As predicted, S. nutans showed greater sensitivity to water stress, particularly with downregulation of non-coding RNAs and upregulation of water stress and catabolism genes. A. gerardii was less sensitive to drought, although $A$. gerardii tended to respond with upregulation in response to drought versus $S$. nutans which downregulated more genes under drier conditions. Surprisingly, A. gerardii only showed minimal gene expression response to increased temperature, while $S$. nutans showed no response. Gene functional annotation suggested that these two species may respond to stress via different mechanisms. Specifically, $A$. gerardii tends to maintain molecular function while $S$. nutans prioritizes avoidance. Sorghastrum nutans may strategize abscisic acid response and catabolism to respond rapidly to stress. These results have important implications for success of these two important grass species under a more variable and extreme climate forecast for the future.
\end{abstract}




\section{Introduction}

Climatic extremes, such as drought and heat waves, are predicted to increase in frequency and magnitude with forecasted climate change (Stocker et al. 2013). These extreme events may significantly impact ecosystem structure and function depending on their severity (Ciais et al. 2005; García-Herrera et al. 2010; Smith 2011; Knapp et al. 2015). Climate extremes may affect plants in species-specific ways, such as through timing of bud development (Bokhorst et al. 2008), variation in tissue die-back (Kreyling et al. 2008), and differences in physiological performance (Hoover et al. 2014a) or chemical composition (AbdElgawad et al. 2014). Several recent studies have found species to respond differentially to extreme events like drought and heat waves (Beierkuhnlein et al. 2011; Hoover et al. 2014a; Nardini et al. 2016). However, the mechanisms that lead to differences in plant performance are not always clear (McDowell et al. 2008). Understanding gene regulation may help explain the mechanisms of plant response to novel stressful environments (Leakey et al. 2009; Swarbreck et al. 2011). Gene regulation may also be more sensitive to periods of extreme climate compared with physiological performance and growth traits that may have delayed response. Likewise, gene regulation may reveal variation which can affect fitness, selection, and adaptation to new environmental conditions (Ouborg and Vriezen 2007; Gibson 2008; Avolio and Smith 2013; Vázquez et al. 2015). However, most molecular studies of plant responses to drought and heat stress are focused on model organisms with limited ecological relevance (Leakey et al. 2009).

Here, we present a comparison of gene regulation responses of two $\mathrm{C}_{4}$ grass species, Andropogon gerardii and Sorghastrum nutans, to an experimentally induced heat wave and drought in the field. These two dominant grasses are native to the tallgrass prairie ecosystem of the Central U.S. and play an important role in determining community and ecosystem structure and function (Smith and Knapp 2003; Whitham et al. 2006; Whitham et al. 2008; Koerner et al. 2014). They are often assumed to be functionally similar (i.e., both closely related phylogenetically, rhizomatous, $\mathrm{C}_{4}$ warm-season tallgrasses, Weaver and Fitzpatrick 1934; Benson and Hartnett 2006; Estep et al. 2014), and both are relatively resistant to stress (Knapp 1985; Swemmer et al. 2006; Tucker et al. 2011). However, A. gerardii and S. nutans differ in physiological response and abundance under different temperature and water availability (Silletti and Knapp 2002; Silletti et al. 2004; Swemmer et al. 2006; Nippert et al. 2009; Hoover et al. 2014b; Hoover et al. 2014a). At the level of gene regulation, A. gerardii has been shown to be more sensitive to thermal stress (Travers et al. 2007; Travers et al. 2010; but see Smith et al. 2016) while $S$. nutans is more sensitive to moderate water stress (Smith et al. 2016; Hoffman and Smith 2017). Specifically, $S$. nutans was more responsive to both a year-round $2^{\circ} \mathrm{C}$ increase in temperature and more variable precipitation patterns (and lower average soil water availability) than $A$. gerardii (Smith et al. 2016). Sorghastrum nutans also showed greater plasticity for dealing with water stress at the gene level (Hoffman and Smith 2017). To date, much of the research assessing sensitivity of these grasses to heat and water stress has focused on chronic, subtle changes in temperature $\left(2^{\circ} \mathrm{C}\right.$ increase in temperature) and water availability (on average $14 \%$ reduction in soil moisture; Fay et al. 2011). It remains unknown whether these two species would regulate genes differently under more extreme conditions, such as heat waves and droughts, which are predicted increase in frequency and severity in the Central US with climate change (Cook et al. 2015).

To increase our mechanistic understanding of the response of $A$. gerardii and $S$. nutans to climate extremes typical of the region, we analyzed the transcriptional profiles of both grass species during an 18-day controlled heat wave under both watered and drought conditions within 
82 natural field plots. As in past research (Travers et al. 2007; Travers et al. 2010; Smith et al.

83 2016), we measured gene expression using heterologous hybridization with cDNA microarrays

84 designed for a closely related model species, Zea mays. We coupled the microarray data with

85 filtering through each species' RNA-seq transcriptome (Hoffman and Smith 2017). We

86 hypothesized that gene regulation (number of genes, functional groups) would differ between $A$.

87 gerardii and $S$. nutans in response to the heat wave under both watered and drought conditions,

88 with these grasses employing different strategies for coping with extreme heat and water stress.

89

90

91

92

93

94

95

96

97

98

\section{Methods}

\section{Site description and experimental treatments}

The study was carried out within the context of an existing long-term climate change experiment, the Rainfall Manipulation Plots (RaMPs), located at the Konza Prairie Biological Station in north-eastern Kansas ( $39^{\circ} 05^{`}$ N, $96^{\circ} 35^{`}$ W). Kansas State University, Manhattan, KS, USA and the Konza Prairie Biological Station granted explicit permission to the authors to sample with minimal impact within the RaMPs. The RaMPs is located in a native, annually burned site and consists of twelve $14 \times 9 \mathrm{~m}$ greenhouse shelters (without walls) equipped with a clear (UV transparent) polyethylene roof to exclude natural rainfall inputs (Fay et al. 2011). Our experimental plots were located in two RaMPs (RaMP 12 and 13) in areas outside the $6 \times 6 \mathrm{~m}$ experimental plots, but still located underneath the shelter infrastructure. Each of these areas is approximately $3 \times 8 \mathrm{~m}$ in size, within which we located a $3 \times 6 \mathrm{~m}$ experimental sampling plot. The RaMP 12 sampling plot was watered from late-May to mid-Aug to create a watered condition, whereas all ambient rainfall was excluded from the RaMP 13 sampling plot to create a drought. For both the watered and drought plots, a controlled high heat treatment was achieved by installing pairs of rectangular infrared heating lamps (Kalglo 2000 W, Kalglo Electronic Co Inc., Bethlehem, PA, USA) (Online Resource Fig. 1). This resulted in a high heat treatment zone with a daytime target maximum of $+8^{\circ} \mathrm{C}$ above ambient midday temperature (Online Resource Fig. 2), alongside ambient temperature treatment zones. The four treatments allowed us to examine the effects of drought and heat individually along with their interaction. The high heat treatment was imposed for an 18-day period (July 17 to August 4), when heat waves have generally occurred in the past (Hoover et al. 2014b).

Prior to initiation of the experiment, canopy temperature in the watered sampling plot was measured using an infrared thermometer mounted on a movable platform (approx. $0.5 \mathrm{~m}$

114 above the canopy). Soil moisture was monitored at a depth of $0-15 \mathrm{~cm}$ with $30-\mathrm{cm}$ time-domain reflectometery probes (Model CS616, Campbell Scientific, Logan, Utah, USA) inserted at a $45^{\circ}$ angle (see supplementary information).

\section{Plant sampling and measurements}

The focal species, A. gerardii and $S$. nutans, are both are rhizomatous $\mathrm{C}_{4}$ grasses that reproduce primarily vegetatively via belowground buds on rhizomes (Brejda et al. 1989; Carter and VanderWeide 2014), which form dense intermixed stands, making it virtually impossible to differentiate between clones in the field (Avolio et al. 2011). We sampled individuals of $A$. gerardii and $S$. nutans from native populations growing within the experimental treatment plots during two sampling campaigns conducted at Day 4 and Day 18 of the heat wave. Each sampling campaign was conducted between 11:00 and 15:00 CDT to allow for collection of leaf temperature and water status (see below). 
127

128

129

130

131

132

133

134

135

136

137

138

139

140

141

142

143

144

145

146

147

148

149

150

151

152

153

154

155

156

157

158

159

160

161

162

163

164

165

166

167

168

169

170

171

172

During each sampling campaign, we sampled two, morphological similar individuals (tiller or ramets, with 3-5 fully expanded leaves) of each species within the high heat zone and ambient temperature zone in both the watered and drought sampling plots $(n=2$ samples per species, four treatments, and two campaign dates, or $\mathrm{n}=16$ per species, $\mathrm{N}=32$ total samples). While a sample size of two per species and treatment combination is relatively small, we believe this sample size was appropriate given that our focus was on broadly detecting interspecific differences under the high heat and drought conditions. Although we did not control for plant genotype, we collected our samples within a limited sampling area $(10 \times 10 \mathrm{~cm})$ to minimize genotypic differences among samples. Leaf tissue was collected from individuals located within each treatment within a five-minute window. For each individual, the first or second fully expanded leaf was randomly selected for genomic analysis to ensure similar leaf age. The entire leaf was clipped and immediately flash-frozen and stored in liquid nitrogen until brought to the laboratory. Immediately after, we measured leaf temperature $\left(\mathrm{T}_{\text {leaf }}\right)$ and midday leaf water potential $\left(\Psi_{\mathrm{mid}}\right)$ on the remaining fully expanded leaf. $\mathrm{T}_{\text {leaf }}$ was measured using a LI-6400 system (LiCOR, Inc., Lincoln, NE, USA). The whole leaf was then collected for determination of midday leaf water potential (LWP) using an Scholander-type pressure chamber (PMS Instruments, Inc., Corvallis, OR, USA).

\section{RNA preparation and microarray hybridization}

Leaf tissue samples were stored in an -80 freezer prior to RNA extraction. Total RNA was extracted from the 32 leaf samples for both species using TRIzol reagent (Invitrogen, Carlsbad, CA) (McCarty 1986), and further purified with the RNeasy kit (Invitrogen, Carlsbad, CA). RNA quantity was measured by a NanoDrop spectrophotometer (Nanodrop products, Thermo Scientific, Wilmington, DE). The verification of RNA quality, preparation of cDNA, and the subsequent steps leading to hybridization and array scanning were performed by Biotechnology Resources of Keck facility at Yale University (http://keck.med.yale.edu/). We used maize spotted cDNA arrays (SAM 1.2, GEO platform GPL4521) produced by the Center for Plant Genomics at Iowa State University for hybridization. The arrays included 15,680 maize cDNA probes (14,118 informative) isolated from maize ear tissue.

\section{Quality control of heterologous hybridizations}

In total, there were eight hybridizations for each species per sampling campaign (Online Resource Table 1). Array image data were collected using GenePix software (Version 6, Axon, Downingtown, PA). Prior to normalization across arrays, features with obvious abnormality and saturated signal were flagged and excluded from statistical analysis. Two steps were taken to minimize the probability of mishybridization and sequence divergence between the focal species and the model species (Leakey et al. 2009). First, we used stringent criteria by excluding spots with signal to noise ratios less than 3 or larger than 10 to decrease the inclusion of crosshybridization artefacts (Verdnik et al. 2002). Second, the cDNA sequences of the maize microarray SAM1.2 (18,862 sequences) were aligned against the de novo RNA-seq transcriptome data sets of $A$. gerardii and S. nutans (Hoffman and Smith 2017), previously generated using Trinity (version 2.1.1, Haas et al. 2013). We only included BLASTN (Altschul et al. 1990; Altschul et al. 1997) hits with an e-value cutoff of $1 \mathrm{e}^{-10}$ and alignment length larger than 150 base pairs from the $A$. gerardii and $S$. nutans transcript data sets. After these two steps, 7,964 and 6,035 probe sequences were included in the analysis, accounting for $61.4 \%$ and $56.6 \%$ of the maize SAM 1.2 array probes for $A$. gerardii and $S$. nutans respectively. 5,109 features 
173 were common to both species. Because features were screened by both the intensity of

174 hybridization signal and sequence similarity, the intensity values of the included features were

175 reliable for further expression analysis. These same techniques have also been validated

176 previously using quantitative real-time PCR (qPCR) (Smith et al. 2016).

177

178

179

180

181

182

183

184

185

186

187

188

189

190

191

192

193

194

195

196

197

198

199

200

201

202

203

204

205

206

207

208

209

210

211

212

213

214

215

216

217

218

\section{Array data normalization and statistical analysis}

An important source of systematic errors in two-color microarray experiments is the different properties of the dyes used to label the two samples (Tseng et al. 2001; Yang et al. 2001; Yang et al. 2002) and the hybridization variability from array to array. We used dye-swap design for the same pair of samples in the hybridizations (Online Resource Table 1) to account for the dye effect (Dabney and Storey 2007). Background signals were removed from median signal intensity and modelled similarly to Travers et al. (2010) to remove the array and dye effect:

$$
y_{i j k}=A_{i}+D_{j}+A_{i} D_{j}+\varepsilon_{i j k},
$$

where $y$ is the median intensity for the $k$ th gene on each array $(i)$ with each dye $(j), A$ is the array effect for each array $(i), D$ is the dye effect for each dye $(j), A D$ is the array $\times$ dye interaction, and $\varepsilon_{i j k}$ is the stochastic error. Residuals from this model were adjusted by the minimum value to produce all positive residuals. To examine overall statistical effects, we used the residuals in the following model:

$$
r_{k l m n o}=S_{l}+W_{m}+T_{n}+C_{o}+S_{l} W_{m}+S_{l} T_{n}+W_{m} T_{n}+\varepsilon_{k l m n o}
$$

where $r$ is the residual for each gene $(k)$ with each species $(l)$, water treatment $(m)$, temperature $(n)$, and sampling date $(o), S$ is the species effect, $W$ is the water treatment effect (plot), $T$ is the temperature effect, and $C$ is the sampling date effect. Residuals were used to generate $\log _{2}$ expression ratios for the four variables: species (A. gerardii / S. nutans), water treatment (watered / droughted), temperature (ambient / heated), date (day 4 / day 18). Any genes with missing signals were removed. We plotted the $\log _{2}$ expression ratio against the $\log _{10}$ intensity for each gene and performed a loess correction to normalize each set of $\log _{2}$ values (Online Resource Fig. 3). Then for each gene without missing values, a linear model was performed to test each main effect (species, water treatment, temperature, and date) as well as selected interactions (species $\times$ water treatment, species $\times$ temperature, and water treatment $\times$ temperature). Because of the variation in genes present across arrays, each model was constructed only if appropriate data was present. In other words, to test species effect, both species had to express the given gene. P-values were adjusted using a Bonferroni correction to account false discovery across multiple tests. All analyses were performed using $\mathrm{R}$ (version 3.3.2).

\section{Functional annotation, enrichment, and clustering}

The functional annotation of transcripts was based on the Trinotate pipeline (version 3.0.1). We matched microarray probe sequences to known sequences using BLAST against the SwissProt annotated database (Apweiler et al. 2004), identified protein sequence homology using HMMER and Pfam (Finn et al. 2011; Finn et al. 2015), and searched for known annotations within eggNOG and GO databases (The Gene Ontology Consortium 2015; Huerta-Cepas et al. 2016). Ontology enrichment was determined using GOSeq (version 3.4, Young et al. 2010), a statistical package for $\mathrm{R}$ which accounts for multiple testing as well as differing probe lengths. Finally, clustering of gene modules was performed using the WGCNA package for R (version 1.51, Langfelder and Horvath 2008) with a minimum module size of five genes. 


\section{Results}

Efficacy of the heat wave and drought treatments and impacts on $\boldsymbol{T}_{\text {leaf }}$ and $\boldsymbol{\Psi}_{\text {mid }}$

On average, the heated (heat wave) treatment resulted in an $8^{\circ} \mathrm{C}$ increase in canopy temperature (Online Resource Fig. 2a). On average, the drought treatment decreased volumetric soil water content from $28 \%$ to $24 \%$ midway through the heat wave (day 9). The high heat treatment further decreased soil water content by $2 \%$ for the watered and $5 \%$ for the drought treatments (Online Resource Fig. 2b). Overall, the combined effect of drought and heat resulted in a drop from $29 \%$ to $22 \%$ volumetric water content. The increase in canopy temperature with the high heat treatment was reflected in greater leaf temperature $\left(\mathrm{T}_{\text {leaf }}\right)$ for both species; $A$. gerardii and $S$. nutans had significantly higher $\mathrm{T}_{\text {leaf }}$ at both day 4 and 18 of the heat wave (Online Resource Fig. 4). Similarly, the decrease in soil water content with the drought and high heat treatment were reflected in greater water stress in both species (i.e., more negative $\Psi_{\text {mid }}$, Online Resource Fig. 4). For A. gerardii, the high heat treatment caused a large decrease in $\Psi_{\text {mid }}$, with this decline greatest at day 4 of the heat wave combined with drought (-0.9 MPa, Online Resource Fig. 4). The decrease in $\Psi_{\text {mid }}$ with the high heat treatment was most pronounced in $S$. nutans after 18 days of heat wave under drought (-1.7 MPa, Online Resource Fig. 4).

\section{Environment affects gene regulation in $A$. gerardii and S. nutans}

Overall, 1131 genes were shared across both species, 1515 were shared across water treatment, 1653 were shared across temperature treatment, and 1390 were shared across date. Species $(p<0.001)$, water treatment $(p<0.001)$, and their interaction $(p<0.001)$ most significantly impacted gene expression. In other words, species gene expression response strongly depended on the drought environment. Temperature was only a weakly significant predictor of gene expression $(p=0.048)$ with no significant species by temperature interaction. Gene expression did not vary across sample date/duration of the heat wave.

\section{Overall differences between $\boldsymbol{A}$. gerardii and $S$. nutans}

Of 1131 genes found in both species, 160 differed significantly in their regulation between species. Genes with greater expression in $A$. gerardii were enriched in cellular metabolic process, biological regulation, and protein metabolic process, while genes with greater expression in $S$. nutans were enriched in negative regulation of metabolism, biological, and cellular processes, macromolecule catabolic process, and protein kinase activity (Fig. 1). Within cellular metabolic process, the most extreme differences were found in a methyltransferase and other transferases, GTP binding protein, Dihydrouridine synthase (Dus), as well as several transcription factors (Table 1). Among biological regulation genes, several transcription factors were strongly upregulated in $A$. gerardii. Protein metabolic processes included several ribosomal-related genes as well as fibrillarin upregulated in $A$. gerardii. Within genes significantly upregulated in $S$. nutans, the negative regulation (inhibition) category consisted of a finger protein as well as several membrane proteins like CMP-sialic acid transporter homolog (Table 1). Macromolecule catabolism genes included several proteasomes, 1,2-alphamannosidase, and a ubiquitin-conjugating enzyme. Among genes annotating to the term "stress", 18 were upregulated in $S$. nutans versus 31 upregulated in $A$. gerardii. Genes annotating broadly to "regulation" showed 91 upregulated in $A$. gerardii versus 74 in $S$. nutans.

Gene clustering was performed for day 18 samples to detect species differences for both plots at the end of the heat wave. Similarly regulated modules or groups of genes may lead to a 
265 greater understanding of gene networks contributing to different species responses. One gene

266

267

268

269

270

271

272

273

274

275

276

277

278

279

280

281

282

283

284

285

286

287

288

289

290

291

292

293

294

295

296

297

298

299

300

301

302

303

304

305

306

307

308

309

310 module significantly explained species differences in the watered treatment $(p<0.001$, Fig. 2a) with genes generally expressed more highly in $S$. nutans. Two gene modules significantly explained species differences in the drought treatment $(p=0.01$, Fig. $2 b$ and $p=0.02$, Fig. $2 c$ respectively). Under drought, genes generally had lower expression in $S$. nutans.

\section{Genes regulated in $A$. gerardii}

In $A$. gerardii, 61 genes were significantly regulated in response to drought $(5 \%$ of 1148 total genes), with 24 genes upregulated under watered conditions and 37 upregulated under drought conditions. Few GO categories had strong enrichment (i.e., few genes per category). The drought treatment showed enrichment in response to osmotic stress, chromatin silencing, and lysosome. The watered treatment suggested greater abundance of xylose metabolism, sucrose metabolism, and ion transport (although each group contained only one gene) (Fig. 3a). Osmotic stress genes included an RNA-binding protein, ribosomal protein S3, and aconitate hydratase (Table 1). Within chromatin silencing genes, two histone acetyltransferases were upregulated under drought. Among all genes, 24 genes annotating to "stress" were upregulated in the watered treatment, versus 29 under drought. Only two genes (both within A. gerardii) responded significantly to temperature. One gene was upregulated in response to higher temperatures (Hsp70 protein); another was downregulated under higher temperatures (high mobility groupbox domain).

\section{Genes regulated in $S$. nutans}

Sorghastrum nutans regulated more genes in response to drought than $A$. gerardii $(23 \%$ of 762 genes total). Of these, 92 showed greater expression in the watered treatment while 82 showed greater expression under drought. Genes upregulated in the watered treatment showed GO enrichment in non-coding RNA (ncRNA) and RNA metabolism and nitrogen response. Genes upregulated under drought showed enrichment in response to water stress, external encapsulating structure, organophosphate metabolism, and cellular catabolism (Fig. 3b). Within the watered treatment ncRNA metabolism genes including ERBB-3 binding ribonuleoprotein, serrate RNA effector molecule, and pseudouridine synthase were upregulated (Table 1).

Sorghastrum nutans in the watered treatment also showed greater expression of aquaporin NIP31, NEP1-interacting protein, and a transcriptional corepressor.

In contrast, $S$. nutans under drought showed greater expression of osmotic stress genes E3 ubiquitin ligase SUD1, 9 aldo-keto reductase, and hydrophobic protein LTI6A (Table 1). Among encapsulating structures, CMP-sialic acid transporter homolog, phosphatidylinositol kinase, pectin acetylesterase 8 , and two glucuronosyltransferases (ranged from fold change of 1.47 to -1.71 ) were upregulated under drought. Catabolism genes within the drought treatment included 26S protease, DNA-directed RNA polymerase II Rpb7p, and phosphatidylinositol kinase. Lastly, the drought treatment showed increased expression of organophosphate metabolism genes including GDP-mannose 4,6 dehydratase, triosephosphate isomerase and phosphatidylinositol-4-phosphate 5-kinase. Among all genes, $12(1.5 \%)$ genes annotating to "stress" were upregulated in the watered treatment, versus $20(2.6 \%)$ under drought.

\section{Discussion}

Increasingly, ecological studies are using molecular techniques to study gene-level responses to global change in non-model organisms (Travers et al. 2007; Leakey et al. 2009; 
311 Alvarez et al. 2015; Smith et al. 2016). Genomic tools like microarrays have revealed

312 mechanisms behind plant environmental responses in natural plant populations (Jackson et al.

313 2002; Travers et al. 2007; Ungerer et al. 2008; Leakey et al. 2009; Travers et al. 2010; Smith et

314 al. 2016). Heterologous hybridization has proven useful for studying non-model organisms when

315 the proper precautions are taken and stringent criteria are utilized to control for

316 mishybridizations (Leakey et al. 2009; Travers et al. 2010; Alvarez et al. 2015). Both

317 environmental (Gong et al. 2005; Hammond et al. 2006; Sharma et al. 2006; Travers et al. 2010;

318 Alvarez et al. 2015) and biotic (Horvath et al. 2007; Broz et al. 2008) stress responses have been

319 explored. Our study used heterologous hybridization to compare transcriptional responses of two

320

321

322

323

324

325

326

327

328

329

330

331

332

333

334

335

336

337

338

339

340

341

342

343

344

345

346

347

348

349

350

351

352

353

354

355 non-model grasses under field conditions. We used stringent criteria to control for mishybridizations, multiple steps to normalize the array data, and sequence alignment with RNA-seq transcriptomes. One significant caveat of the microarray technique is the inability of microarray technology to distinguish between two scenarios: no microarray signal due to true low expression versus no microarray signal due to probe-to-gene mismatch. In other words, this study is limited to low versus high expression contrasts while excluding presence/absence analysis, and may fail to detect larger, significant shifts in gene expression. Moreover, these two species have almost certainly evolved unique genes to adapt to harsh conditions sometimes experienced in the tallgrass prairie. These species-specific genes may be the most insightful but are undetectable using these methods.

We expected that $A$. gerardii and $S$. nutans, two closely related and functionally similar species, would differ in their gene responses to heat-wave and drought. Specifically, S. nutans would regulate a greater number of genes from different groups compared with A. gerardii. This expectation was based on past evidence for greater sensitivity of $S$. nutans to more moderate water stress (Nippert et al. 2009; Hoover et al. 2014a; Smith et al. 2016). Overall, our hypothesis was supported; S. nutans had greater sensitivity to the imposed drought compared to A. gerardii in the percentage of regulated transcripts. Despite similar $T_{\text {leaf }}$ and $\Psi_{\text {mid }}$ measurements, $A$. gerardii appeared less responsive with a smaller proportion of genes (5\%) exhibiting a significant change under drought. A similar pattern of gene regulation was observed when $A$. gerardii and $S$. nutans were exposed to more moderate changes in water availability in the field (Smith et al. 2016). Thus, in line with past research, our results suggest that $A$. gerardii is more resistant to and/or better able to cope with water stress than S. nutans. According to gene modules detected using statistical clustering, $S$. nutans genes tended toward downregulation on day 18 of the drought compared to A. gerardii (Fig. 2), which could represent a surpassed stress response threshold. Sorghastrum nutans has also shown loss of function under stress with respect to net photosynthetic rate and biomass production (Hoover et al. 2014a).

Despite strong support for the non-additive effects of water and temperature stress in some systems (Atkinson and Urwin 2012; Johnson et al. 2014; Suzuki et al. 2014), the two did not show a significant interaction. However, previous work comparing these two species also found no environmental interaction (Hoover et al. 2014a). In our study, only two genes within $A$. gerardii responded to the high heat treatment. Previous ecophysiological research has shown greater relative temperature sensitivity in A. gerardii (Nippert et al. 2009). Gene expression did not vary across sampling date, despite evidence for plasticity in other species (Hayano-Kanashiro et al. 2009; Meyer et al. 2014). However, it is important to acknowledge that fewer genes overlapped across sample date, and only these genes were contrasted. Many genes may have been expressed during the first sampling date but not during the second date and vice versa. 
Over all treatments, A. gerardii tended to have greater expression of metabolic and regulatory genes compared to $S$. nutans, suggesting it maintains high levels of metabolic function in many environmental conditions and may strategize plasticity at the regulatory level (i.e., utilizes more transcription factors, tRNA enzymes, and ribosomal enzymes). In other words, gene expression remains fairly constant but may be modified downstream. Expression of transcription factors has been widely implicated in drought adaptation and response (YamaguchiShinozaki and Shinozaki 2006; Yoshida et al. 2015; Kudo et al. 2016; Gahlaut et al. 2016). On the other hand, greater transcription of negative regulators and catabolism genes in S. nutans may reflect an ability to respond more rapidly to drought stress. Over-expression of negatively regulating PHD finger proteins in Arabidopsis inhibits pathways and leads to enhanced stress tolerance (Wei et al. 2015) and the $26 \mathrm{~S}$ proteastome helps modulate ABA response as well as degrade proteins not needed under non-stressed conditions (Stone 2014). Both species appear equipped to handle stressful conditions, though $S$. nutans seems to focus on rapid response via molecular breakdown and pathway inhibition whereas $A$. gerardii maintains higher levels of metabolic process and regulates transcription via transcription factors. Due to multiple statistical tests performed, only the most significant genes responding to drought were examined. Only two of these overlapped in A. gerardii and S. nutans, further highlighting their different drought response strategies.

Andropogon gerardii has previously shown greater ecophysiological response to temperature (Nippert et al. 2009), but may actually be less sensitive at the gene expression level to mild temperature stress (Smith et al. 2016). A consensus regarding temperature response may remain elusive considering only two genes significantly responded to temperature in A. gerardii. Hsp70 is well known to be upregulated under stress to assist protein folding (Hayano-Kanashiro et al. 2009; Wang et al. 2015), while high mobility group (HMG) genes are known to be negatively correlated with stress response (Kim et al. 2010). The general lack of response may be due to our stringent gene filtering criteria, but may also reflect presence of unique genes in these species. Non-targeted methods (such as RNA-seq, Hoffman and Smith 2017) have been successful in these species and would likely reveal more comprehensive differences under temperature extremes.

Of osmotic stress-related genes upregulated in A. gerardii in response to drought, Glycine-rich RNA-binding protein 2 is known to have RNA chaperone activity during abiotic stress (Kim et al. 2007), 40S ribosomal protein may be upregulated to compensate for mild osmotic stress (Ma et al. 2016), and aconitate hydratase has been shown to increase under water and heat stress (Johnson et al. 2014) in a compensatory manner due to its sensitivity to oxidative damage (Budak et al. 2013). Osmotic stress-related genes were also upregulated in S. nutans under drought, however their function was quite different. E3 ubiquitin ligase is understood to play a role in regulating response to ABA (Doblas et al. 2013; Zhao et al. 2014), aldo-keto reductase 4C9 is involved in scavenging toxins produced under stress (Simpson et al. 2009), and hydrophobic LTI6A is a transmembrane protein which responds to low temperature stress, drought, and ABA (Wang et al. 2016). These focal genes tied to osmotic stress response suggest that while both species are responding to drought, their strategies differ. In this case, $S$. nutans not only regulates a greater percentage of genes but also focuses on ABA response, whereas $A$. gerardii appears to upregulate genes to compensate for lost function. Among its many roles, ABA may help with stomatal closure and drought avoidance (Jones and Mansfield 1970).

Within S. nutans, ncRNAs (transcriptional regulators) declined under drought, which have been shown to downregulate in response to drought (Hackenberg et al. 2015). In this study, 
402 many of these genes mapped to transcription factors or RNA binding, which are typically 403 upregulated under drought (Yamaguchi-Shinozaki and Shinozaki 2006; Yoshida et al. 2015; 404 Kudo et al. 2016; Gahlaut et al. 2016; but see Baldoni et al. 2015). This could indicate that $S$. 405 nutans experienced mechanistic loss of function under drought conditions. Catabolism related 406 genes upregulated under drought may indicate salvaging of important functions. For example, 407 phosphatidylinositol-4-phosphate 5-kinase is known to modulate ABA response as well as 408 prevent breakdown of proline, an important ROS scavenger (Leprince et al. 2014). The 26S 409 protease regulatory subunit lends additional breakdown of molecules potentially involved in 410 signaling (Stone 2014). Similarly, RNA polymerase subunit Rpb7p is thought to help degrade 411 mRNAs as a counteractive measure (Shalem et al. 2011). Of the genes not involved in cellular 412 catabolism, some were tied to cell wall integrity (e.g., pectin acetylesterase) and may serve as a 413 last resort for survival under extreme stress (Houston et al. 2016). Meanwhile, few genes 414 suggested loss of function or disassembly role in $A$. gerardii, which further emphasizes $S$. 415 nutans' greater sensitivity to drought stress. Of note is A. gerardii's more consistent regulation of 416 stress transcripts: this species shifted from $2.1 \%$ to $2.5 \%$ "stress" annotations following drought, 417 while $S$. nutans shifted from $1.6 \%$ to $2.6 \%$ "stress" annotations. This could mean that $A$. gerardii 418 tolerates stress and avoids sensitivity by constitutively expressing some stress responses. This 419 makes sense considering the broad array of stressors $A$. gerardii is likely to experience (Hulbert 420 1988; Turner and Knapp 1996; Silletti et al. 2004; Swemmer et al. 2006; Koerner et al. 2014). Overall, these results suggest that $S$. nutans' ecophysiological sensitivity may be mechanistically tied to downregulation of genes under stress coupled with rapid avoidance strategies, such as the regulation of ABA. Andropogon gerardii's apparent lack of sensitivity may result from upregulation of stress sensitive transcripts coupled with maintenance of cellular processes despite extreme stress.

\section{Conclusions}

Our results suggest that $A$. gerardii is more resistant to extremes in water stress and does not downregulate as many processes as $S$. nutans. Surprisingly, response to the heat wave was minimal. While $A$. gerardii contributes proportionally more aboveground biomass (Smith and Knapp 2003) and is an important mediator of species diversity in the tallgrass prairie ecosystem (Collins 2000; Smith et al. 2004), S. nutans is able to attain greater photosynthetic rates that could be linked to carbon storage (Hoover et al. 2014a). Differences in sensitivity and stress response mechanisms could ultimately alter community structure and ecosystem function in the tallgrass prairie ecosystem. 


\section{Acknowledgements}

438 We thank S. Yuan for preparing the samples for this study. J.M. Blair in part conceived the 439 rainfall manipulation plots experiment. We thank J.C. Cahill for comments on a previous version 440 of the manuscript. 


\section{References}

442 AbdElgawad H, Peshev D, Zinta G, Van Den Ende W, Janssens IA, Asard H (2014) Climate

443

444

445

446

447

448

449

450

451

452

453

454

455

456

457

458

459

460

461

462

463

464

465

466

467

468

469

470

471

472

473

474

475

476

477

478

479

480

481

482

483

484

485

486 extreme effects on the chemical composition of temperate grassland species under ambient and elevated CO2: A comparison of fructan and non-fructan accumulators. PLoS One 9: . doi: 10.1371/journal.pone.0092044

Altschul SF, Gish W, Miller W, Myers EW, Lipman DJ (1990) Basic local alignment search tool. J Mol Biol 215:403-410 . doi: 10.1016/S0022-2836(05)80360-2

Altschul SF, Madden TL, Schäffer AA, Zhang J, Zhang Z, Miller W, Lipman DJ (1997) Gapped BLAST and PSI-BLAST: a new generation of protein database search programs. Nucleic Acids Res 25:3389-3402 . doi: 9254694

Alvarez M, Schrey AW, Richards CL (2015) Ten years of transcriptomics in wild populations: what have we learned about their ecology and evolution? Mol Ecol 24:710-725 . doi: $10.1111 / \mathrm{mec} .13055$

Apweiler R, Bairoch A, Wu CH, Barker WC, Boeckmann B, Ferro S, Gasteiger E, Huang H, Lopez R, Magrane M, Martin MJ, Natale DA, O’Donovan C, Redaschi N, Yeh L-SL (2004) UniProt: the Universal Protein knowledgebase. Nucleic Acids Res 32:D115-D119 . doi: 10.1093/nar/gkh131

Atkinson NJ, Urwin PE (2012) The interaction of plant biotic and abiotic stresses: From genes to the field. J. Exp. Bot. 63:3523-3544

Avolio ML, Chang CC, Smith MD (2011) Assessing Fine-Scale Genotypic Structure of a Dominant Species in Native Grasslands. Am Midl Nat 165:211-224 . doi: 10.1674/00030031-165.2.211

Avolio ML, Smith MD (2013) Mechanisms of selection: Phenotypic differences among genotypes explain patterns of selection in a dominant species. Ecology 94:953-965 . doi: $10.1890 / 12-1119.1$

Baldoni E, Genga A, Cominelli E (2015) Plant MYB transcription factors: Their role in drought response mechanisms. Int. J. Mol. Sci. 16:15811-15851

Beierkuhnlein C, Thiel D, Jentsch A, Willner E, Kreyling J (2011) Ecotypes of European grass species respond differently to warming and extreme drought. J Ecol 99:703-713 . doi: 10.1111/j.1365-2745.2011.01809.x

Benson EJ, Hartnett DC (2006) The Role of Seed and Vegetative Reproduction in Plant Recruitment and Demography in Tallgrass Prairie. Plant Ecol 187:163-178 . doi: 10.1007/s11258-005-0975-y

Bokhorst S, Bjerke JW, Bowles FW, Melillo J, Callaghan T V., Phoenix GK (2008) Impacts of extreme winter warming in the sub-Arctic: Growing season responses of dwarf shrub heathland. Glob Chang Biol 14:2603-2612 . doi: 10.1111/j.1365-2486.2008.01689.x

Brejda JJ, Moser LE, Waller SS (1989) Rhizome and Tiller Development of Three Nebraska Sandhills Warm-Season Grasses. Proc Elev North Am Prairie Conf 211-215

Broz AK, Manter DK, Callaway RM, Paschke MW, Vivanco JM (2008) A molecular approach to understanding plant-plant interactions in the context of invasion biology. Funct Plant Biol 35:1123-1134 . doi: 10.1071/FP08155

Budak H, Akpinar BA, Unver T, Turktas M (2013) Proteome changes in wild and modern wheat leaves upon drought stress by two-dimensional electrophoresis and nanoLC-ESI-MS/MS. Plant Mol Biol 83:89-103 . doi: 10.1007/s11103-013-0024-5

Carter DL, VanderWeide BL (2014) Belowground bud production is linked to population establishment in Sorghastrum nutans (Poaceae). Plant Ecol 215:977-986 . doi: 
487

488

489

490

491

492

493

494

495

496

497

498

499

500

501

502

503

504

505

506

507

508

509

510

511

512

513

514

515

516

517

518

519

520

521

522

523

524

525

526

527

528

529

530

531

532

\section{$10.1007 / \mathrm{s} 11258-014-0353-8$}

Ciais P, Reichstein M, Viovy N, Granier A, Ogée J, Allard V, Aubinet M, Buchmann N, Bernhofer C, Carrara A, Chevallier F, De Noblet N, Friend AD, Friedlingstein P, Grünwald T, Heinesch B, Keronen P, Knohl A, Krinner G, Loustau D, Manca G, Matteucci G, Miglietta F, Ourcival JM, Papale D, Pilegaard K, Rambal S, Seufert G, Soussana JF, Sanz MJ, Schulze ED, Vesala T, Valentini R (2005) Europe-wide reduction in primary productivity caused by the heat and drought in 2003. Nature 437:529-533 . doi: 10.1038 /nature03972

Collins SL (2000) Disturbance Frequency and Community Stability in Native Tallgrass Prairie. Am Nat 155:311-325 . doi: 10.1086/303326

Cook BI, Ault TR, Smerdon JE (2015) Unprecedented 21st century drought risk in the American Southwest and Central Plains. Sci Adv 1: . doi: 10.1126/sciadv.1400082

Dabney AR, Storey JD (2007) A new approach to intensity-dependent normalization of twochannel microarrays. Biostatistics 8:128-139 . doi: 10.1093/biostatistics/kxj038

Doblas VG, Amorim-Silva V, Posé D, Rosado A, Esteban A, Arró M, Azevedo H, Bombarely A, Borsani O, Valpuesta V, Ferrer A, Tavares RM, Botella MA (2013) The SUD1 gene encodes a putative E3 ubiquitin ligase and is a positive regulator of 3-hydroxy-3methylglutaryl coenzyme a reductase activity in Arabidopsis. Plant Cell 25:728-43 . doi: $10.1105 /$ tpc. 112.108696

Ellegren H (2014) Genome sequencing and population genomics in non-model organisms. Trends Ecol Evol 29:51-63 . doi: 10.1016/j.tree.2013.09.008

Estep MC, McKain MR, Vela Diaz D, Zhong J, Hodge JG, Hodkinson TR, Layton DJ, Malcomber ST, Pasquet R, Kellogg E a (2014) Allopolyploidy, diversification, and the Miocene grassland expansion. Proc Natl Acad Sci 111:15149-15154 . doi: 10.1073/pnas. 1404177111

Fay PA, Blair JM, Smith MD, Nippert JB, Carlisle JD, Knapp AK (2011) Relative effects of precipitation variability and warming on tallgrass prairie ecosystem function.

Biogeosciences 8:3053-3068 . doi: 10.5194/bg-8-3053-2011

Finn RD, Clements J, Eddy SR (2011) HMMER web server: Interactive sequence similarity searching. Nucleic Acids Res 39: . doi: 10.1093/nar/gkr367

Finn RD, Coggill P, Eberhardt RY, Eddy SR, Mistry J, Mitchell AL, Potter SC, Punta M, Qureshi M, Sangrador-Vegas A, Salazar GA, Tate J, Bateman A (2015) The Pfam protein families database: towards a more sustainable future. Nucleic Acids Res 279-285 . doi: 10.1093/nar/gkv1344

Gahlaut V, Jaiswal V, Kumar A, Gupta PK (2016) Transcription factors involved in drought tolerance and their possible role in developing drought tolerant cultivars with emphasis on wheat (Triticum aestivum L.). Theor Appl Genet 129:2019-2042 . doi: 10.1007/s00122016-2794-z

García-Herrera R, Díaz J, Trigo RM, Luterbacher J, Fischer EM (2010) A Review of the European Summer Heat Wave of 2003. Crit. Rev. Environ. Sci. Technol. 40:267-306

Gibson G (2008) The environmental contribution to gene expression profiles. Nat Rev Genet 9:575-581 . doi: 10.1038/nrg2383

Gong Q, Li P, Ma S, Indu Rupassara S, Bohnert HJ (2005) Salinity stress adaptation competence in the extremophile Thellungiella halophila in comparison with its relative Arabidopsis thaliana. Plant J 44:826-839 . doi: 10.1111/j.1365-313X.2005.02587.x

Haas BJ, Papanicolaou A, Yassour M, Grabherr M, Blood PD, Bowden J, Couger MB, Eccles D, 
533

534

535

536

537

538

539

540

541

542

543

544

545

546

547

548

549

550

551

552

553

554

555

556

557

558

559

560

561

562

563

564

565

566

567

568

569

570

571

572

573

574

575

576

577

578

Li B, Lieber M, MacManes MD, Ott M, Orvis J, Pochet N, Strozzi F, Weeks N, Westerman R, William T, Dewey CN, Henschel R, LeDuc RD, Friedman N, Regev A (2013) De novo transcript sequence reconstruction from RNA-seq using the Trinity platform for reference generation and analysis. Nat Protoc 8:1494-1512 . doi: 10.1038/nprot.2013.084

Hackenberg M, Gustafson P, Langridge P, Shi BJ (2015) Differential expression of microRNAs and other small RNAs in barley between water and drought conditions. Plant Biotechnol J 13:2-13 . doi: 10.1111/pbi.12220

Hammond JP, Bowen HC, White PJ, Mills V, Pyke KA, Baker AJM, Whiting SN, May ST, Broadley MR (2006) A comparison of the Thlaspi caerulescens and Thlaspi arvense shoot transcriptomes. New Phytol 170:239-260 . doi: 10.1111/j.1469-8137.2006.01662.x

Hayano-Kanashiro C, Calderón-Vásquez C, Ibarra-Laclette E, Herrera-Estrella L, Simpson J (2009) Analysis of gene expression and physiological responses in three Mexican maize landraces under drought stress and recovery irrigation. PLoS One 4: . doi: 10.1371/journal.pone.0007531

Hoffman AM, Smith MD (2017) Gene expression differs in co-dominant prairie grasses under drought. Mol Ecol Resour. doi: 10.1111/1755-0998.12733

Hoover DL, Knapp AK, Smith MD (2014a) Contrasting sensitivities of two dominant C4 grasses to heat waves and drought. Plant Ecol 215:721-731 . doi: 10.1007/s11258-014-0345-8

Hoover DL, Knapp AK, Smith MD (2014b) Resistance and resilience of a grassland ecosystem to climate extremes. Ecology 95:2646-2656 . doi: 10.1890/13-2186.1

Horvath DP, Llewellyn D, Clay SA (2007) Heterologous Hybridization of Cotton Microarrays with Velvetleaf (Abutilon Theophrasti) Reveals Physiological Responses Due to Corn Competition. Weed Sci 55:546-557 . doi: 10.1614/WS-07-008.1

Houston K, Tucker MR, Chowdhury J, Shirley N, Little A (2016) The Plant Cell Wall: A Complex and Dynamic Structure As Revealed by the Responses of Genes under Stress Conditions. Front Plant Sci 7:1-18 . doi: 10.3389/fpls.2016.00984

Huerta-Cepas J, Szklarczyk D, Forslund K, Cook H, Heller D, Walter MC, Rattei T, Mende DR, Sunagawa S, Kuhn M, Jensen LJ, von Mering C, Bork P (2016) eggNOG 4.5: a hierarchical orthology framework with improved functional annotations for eukaryotic, prokaryotic and viral sequences. Nucleic Acids Res 44:286-293 . doi: 10.1093/nar/gkv1248

Hulbert LC (1988) Causes of Fire Effects in Tallgrass Prairie. Ecology 69:46-58 . doi: $10.2307 / 1943159$

Jackson RB, Linder CR, Lynch M, Purugganan M, Somerville S, Thayer SS (2002) Linking molecular insight and ecological research. Trends Ecol Evol 17:409-414 . doi: $10.1016 / \mathrm{S} 0169-5347(02) 02571-5$

Johnson SM, Lim F-L, Finkler A, Fromm H, Slabas AR, Knight MR (2014) Transcriptomic analysis of Sorghum bicolor responding to combined heat and drought stress. BMC Genomics 15: . doi: 10.1186/1471-2164-15-456

Jones RJ, Mansfield TA (1970) Suppression of Stomatal Opening in Leaves Treated with Abscisic Acid. J Exp Bot 21:714-719 . doi: 10.1093/jxb/21.3.714

Kim JM, To TK, Nishioka T, Seki M (2010) Chromatin regulation functions in plant abiotic stress responses. Plant, Cell Environ 33:604-611 . doi: 10.1111/j.1365-3040.2009.02076.x

Kim JY, Park SJ, Jang B, Jung C-H, Ahn SJ, Goh C-H, Cho K, Han O, Kang H (2007) Functional characterization of a glycine-rich RNA-binding protein 2 in Arabidopsis thaliana under abiotic stress conditions. Plant J 50:439-451 . doi: 10.1111/j.1365313X.2007.03057.x 
579

580

581

582

583

584

585

586

587

588

589

590

591

592

593

594

595

596

597

598

599

600

601

602

603

604

605

606

607

608

609

610

611

612

613

614

615

616

617

618

619

620

621

622

623

624

Knapp AK (1985) Effect of Fire and Drought on the Ecophysiology of Andropogon gerardii and Panicum virgatum in a Tallgrass Prairie. Ecology 66:1309-1320 . doi: 10.2307/1939184 Knapp AK, Hoover DL, Wilcox KR, Avolio ML, Koerner SE, La Pierre KJ, Loik ME, Luo Y, Sala OE, Smith MD (2015) Characterizing differences in precipitation regimes of extreme wet and dry years: implications for climate change experiments. Glob Chang Biol 21:26242633 . doi: $10.1111 / \mathrm{gcb} .12888$

Koerner SE, Burkepile DE, Fynn RWS, Burns CE, Eby S, Govender N, Hagenah N, Matchett KJ, Thompson DI, Wilcox KR, Collins SL, Kirkman KP, Knapp AK, Smith MD (2014) Plant community response to loss of large herbivores differs between North American and South African savanna grasslands. Ecology 95:808-816 . doi: 10.1890/13-1828.1

Kreyling J, Wenigmann M, Beierkuhnlein C, Jentsch A (2008) Effects of extreme weather events on plant productivity and tissue die-back are modified by community composition. Ecosystems 11:752-763 . doi: 10.1007/s10021-008-9157-9

Kudo M, Kidokoro S, Yoshida T, Mizoi J, Todaka D, Fernie AR, Shinozaki K, YamaguchiShinozaki K (2016) Double overexpression of DREB and PIF transcription factors improves drought stress tolerance and cell elongation in transgenic plants. Plant Biotechnol J. doi: $10.1111 /$ pbi.12644

Langfelder P, Horvath S (2008) WGCNA: an R package for weighted correlation network analysis. BMC Bioinformatics 9:559 . doi: 10.1186/1471-2105-9-559

Leakey ADB, Ainsworth EA, Bernard SM, Markelz RJC, Ort DR, Placella SA, Rogers A, Smith MD, Sudderth EA, Weston DJ, Wullschleger SD, Yuan S (2009) Gene expression profiling: Opening the black box of plant ecosystem responses to global change. Glob Chang Biol 15:1201-1213 . doi: 10.1111/j.1365-2486.2008.01818.x

Leprince A-S, Magalhaes N, De Vos D, Bordenave M, Crilat E, Clément G, Meyer C, Munnik T, Savouré A (2014) Involvement of Phosphatidylinositol 3-kinase in the regulation of proline catabolism in Arabidopsis thaliana. Front Plant Sci 5:772 . doi: 10.3389/fpls.2014.00772

Ma J, Dong W, Zhang D, Gao X, Jiang L, Shao Y, Tong D, Li C (2016) Proteomic profiling analysis reveals that glutathione system plays important roles responding to osmotic stress in wheat ( Triticum aestivum L.) roots. PeerJ 4:e2334 . doi: 10.7717/peerj.2334

McCarty DR (1986) A simple method for extraction of RNA from maize tissue. Maize Genet Coop Newsl 60:

McDowell N, Pockman WT, Allen CD, Breshears DD, Cobb N, Kolb T, Plaut J, Sperry J, West A, Williams DG, Yepez E a (2008) Mechanisms of plant survival and mortality during drought: why do some plants survive while others succumb to drought? New Phytol 178:719-739 . doi: 10.1111/j.1469-8137.2008.02436.x

Meyer E, Aspinwall MJ, Lowry DB, Palacio-Mejía JD, Logan TL, Fay P a, Juenger TE (2014) Integrating transcriptional, metabolomic, and physiological responses to drought stress and recovery in switchgrass (Panicum virgatum L.). BMC Genomics 15: . doi: 10.1186/14712164-15-527

Nardini A, Casolo V, Dal Borgo A, Savi T, Stenni B, Bertoncin P, Zini L, Mcdowell NG (2016) Rooting depth, water relations and non-structural carbohydrate dynamics in three woody angiosperms differentially affected by an extreme summer drought. Plant, Cell Environ 39:618-627 . doi: 10.1111/pce.12646

Nippert JB, Fay PA, Carlisle JD, Knapp AK, Smith MD (2009) Ecophysiological responses of two dominant grasses to altered temperature and precipitation regimes. Acta Oecologica 35:400-408 . doi: 10.1016/j.actao.2009.01.010 
625 Ouborg NJ, Vriezen WH (2007) An ecologist's guide to ecogenomics. J Ecol 95:8-16 . doi:

$626 \quad 10.1111 /$ j. $1365-2745.2006 .01197 . x$

627

628

629

630

631

632

633

634

635

636

637

638

639

640

641

642

643

644

645

646

647

648

649

650

651

652

653

654

655

656

657

658

659

660

661

662

663

664

665

666

667

668

669

670

Shalem O, Groisman B, Choder M, Dahan O, Pilpel Y (2011) Transcriptome kinetics is governed by a genome-wide coupling of mRNA production and degradation: A role for RNA pol II. PLoS Genet 7: . doi: 10.1371/journal.pgen.1002273

Sharma N, Cram D, Huebert T, Zhou N, Parkin IAP (2006) Exploiting the wild crucifer Thlaspi arvense to identify conserved and novel genes expressed during a plant's response to cold stress. Plant Mol Biol 63:171-184 . doi: 10.1007/s11103-006-9080-4

Silletti A, Knapp A (2002) Long-term responses of the grassland co-dominants Andropogon gerardii and Sorghastrum nutans to changes in climate and management. Plant Ecol 163:1522 . doi: 10.1023/A:1020320214750

Silletti AM, Knapp AK, Blair JM (2004) Competition and coexistence in grassland codominants: responses to neighbour removal and resource availability. Can J Bot 82:450-460 . doi: 10.1139/b04-016

Simpson PJ, Tantitadapitak C, Reed AM, Mather OC, Bunce CM, White SA, Ride JP (2009) Characterization of Two Novel Aldo-Keto Reductases from Arabidopsis: Expression Patterns, Broad Substrate Specificity, and an Open Active-Site Structure Suggest a Role in Toxicant Metabolism Following Stress. J Mol Biol 392:465-480 . doi: 10.1016/j.jmb.2009.07.023

Smith MD (2011) An ecological perspective on extreme climatic events: a synthetic definition and framework to guide future research. J Ecol 99:656-663 . doi: 10.1111/j.13652745.2011.01798.x

Smith MD, Hoffman AM, Avolio ML (2016) Gene expression patterns of two dominant tallgrass prairie species differ in response to warming and altered precipitation. Sci Rep 1-14 . doi: $10.1038 /$ srep25522

Smith MD, Knapp AK (2003) Dominant species maintain ecosystem function with non-random species loss. Ecol Lett 6:509-517 . doi: 10.1046/j.1461-0248.2003.00454.x

Smith MD, Wilcox J, Kelly T, Knapp AK (2004) Dominance not richness determines invasibility of tallgrass prairie. Oikos 2:253-262

Stocker TF, Qin D, Plattner G-K, Tignor M, Allen SK, Boschung J, Nauels A, Xia Y, Bex V, Midgley PM (2013) IPCC, 2013: Climate Change 2013: The Physical Science Basis. Contribution of Working Group I to the Fifth Assessment Report of the Intergovernmental Panel on Climate Change. Cambridge, United Kingdom and New York, NY, USA

Stone SL (2014) The role of ubiquitin and the 26S proteasome in plant abiotic stress signaling. Front Plant Sci 5:135 . doi: 10.3389/fpls.2014.00135

Suzuki N, Rivero RM, Shulaev V, Blumwald E, Mittler R (2014) Abiotic and biotic stress combinations. New Phytol 203:32-43 . doi: 10.1111/nph.12797

Swarbreck SM, Sudderth E a., St.Clair SB, Salve R, Castanha C, Torn MS, Ackerly DD, Andersen GL (2011) Linking leaf transcript levels to whole plant analyses provides mechanistic insights to the impact of warming and altered water availability in an annual grass. Glob Chang Biol 17:1577-1594 . doi: 10.1111/j.1365-2486.2010.02359.x

Swemmer AM, Knapp AK, Smith MD (2006) Growth responses of two dominant C4 grass species to altered water availability. Int J Plant Sci 167:1001-1010 . doi: 10.1086/505611

The Gene Ontology Consortium (2015) Gene Ontology Consortium: going forward. Nucleic Acids Res 43:1049-1056 . doi: 10.1093/nar/gku1179

Travers SE, Smith MD, Bai J, Hulbert SH, Leach JE, Schnable PS, Knapp AK, Milliken GA, 
671

672

673

674

675

676

677

678

679

680

681

682

683

684

685

686

687

688

689

690

691

692

693

694

695

696

697

698

699

700

701

702

703

704

705

706

707

708

709

710

711

712

713

714

715

716

Fay PA, Saleh A, Garrett KA (2007) Ecological genomics: making the leap from model systems in the lab to native populations in the field. Front Ecol Environ 5:19-24 . doi: 10.1890/1540-9295(2007)5[19:EGMTLF]2.0.CO;2

Travers SE, Tang Z, Caragea D, Garrett KA, Hulbert SH, Leach JE, Bai J, Saleh A, Knapp AK, Fay PA, Nippert J, Schnable PS, Smith MD (2010) Variation in gene expression of Andropogon gerardii in response to altered environmental conditions associated with climate change. J Ecol 98:374-383 . doi: 10.1111/j.1365-2745.2009.01618.x

Tseng GC, Oh MK, Rohlin L, Liao JC, Wong WH (2001) Issues in cDNA microarray analysis: quality filtering, channel normalization, models of variations and assessment of gene effects. Nucleic Acids Res 29:2549-2557 . doi: 10.1093/nar/29.12.2549

Tucker SS, Craine JM, Nippert JB (2011) Physiological drought tolerance and the structuring of tallgrass prairie assemblages. Ecosphere 2: . doi: 10.1890/ES11-00023.1

Turner CL, Knapp AK (1996) Responses of a C 4 Grass and Three C 3 Forbs to Variation in Nitrogen and Light in Tallgrass Prairie. Ecology 77:1738-1749 . doi: 10.2307/2265779

Ungerer MC, Johnson LC, Herman MA (2008) Ecological genomics: understanding gene and genome function in the natural environment. Heredity (Edinb) 100:178-183 . doi: 10.1038/sj.hdy.6800992

Vázquez DP, Gianoli E, Morris WF, Bozinovic F (2015) Ecological and evolutionary impacts of changing climatic variability. Biol Rev 7: . doi: 10.1111/brv.12216

Verdnik D, Handran S, Pickett S (2002) Key considerations for accurate microarray scanning and image analysis. In: Kamberova G (ed) DNA arrray image analysis: nuts and bolts. DNA Press, Salem, MA, pp 83-98

Voesenek LACJ, Van Veen H, Sasidharan R (2014) Learning from nature: The use of non-model species to identify novel acclimations to flooding stress. AoB Plants 6

Wang W, Qin Q, Sun F, Wang Y, Xu D, Li Z, Fu B (2016) Genome-Wide Differences in DNA Methylation Changes in Two Contrasting Rice Genotypes in Response to Drought Conditions. Front Plant Sci 7:1-13 . doi: 10.3389/fpls.2016.01675

Wang X, Dinler BS, Vignjevic M, Jacobsen S, Wollenweber B (2015) Physiological and proteome studies of responses to heat stress during grain filling in contrasting wheat cultivars. Plant Sci 230:33-50 . doi: 10.1016/j.plantsci.2014.10.009

Weaver JE, Fitzpatrick TJ (1934) The Prairie. Ecol. Monogr. 4

Wei W, Zhang Y-Q, Tao J-J, Chen H-W, Li Q-T, Zhang W-K, Ma B, Lin Q, Zhang J-S, Chen SY (2015) The Alfin-like homeodomain finger protein AL5 suppresses multiple negative factors to confer abiotic stress tolerance in Arabidopsis. Plant J 81:871-883 . doi: $10.1111 /$ tpj. 12773

Whitham TG, Bailey JK, Schweitzer JA, Shuster SM, Bangert RK, LeRoy CJ, Lonsdorf E V, Allan GJ, DiFazio SP, Potts BM, Fischer DG, Gehring C a, Lindroth RL, Marks JC, Hart SC, Wimp GM, Wooley SC (2006) A framework for community and ecosystem genetics: from genes to ecosystems. Nat Rev Genet 7:510-523 . doi: 10.1038/nrg1877

Whitham TG, DiFazio SP, Schweitzer JA, Shuster SM, Allan GJ, Bailey JK, Woolbright SA (2008) Extending Genomics to Natural Communities and Ecosystems. Science 320:492495 . doi: $10.1126 /$ science. 1153918

Yamaguchi-Shinozaki K, Shinozaki K (2006) Transcriptional regulatory networks in cellular responses and tolerance to dehydration and cold stresses. Annu Rev Plant Biol 57:781-803 . doi: 10.1146/annurev.arplant.57.032905.105444

Yang YH, Dudoit S, Luu P, Lin DM, Peng V, Ngai J, Speed TP (2002) Normalization for cDNA 
717 microarray data: a robust composite method addressing single and multiple slide systematic variation. Nucleic Acids Res 30: . doi: 10.1093/nar/30.4.e15

Yang YH, Dudoit S, Luu P, Speed TP (2001) Normalization for cDNA microarray data. In: Microarrays Optical Technologies and Informatics. pp 141-152

Yoshida T, Fujita Y, Maruyama K, Mogami J, Todaka D, Shinozaki K, Yamaguchi-Shinozaki K (2015) Four A rabidopsis AREB/ABF transcription factors function predominantly in gene expression downstream of SnRK2 kinases in abscisic acid signalling in response to osmotic stress. Plant Cell Environ 38:35-49 . doi: 10.1111/pce.12351

Young MD, Wakefield MJ, Smyth GK, Oshlack A (2010) Gene ontology analysis for RNA-seq: accounting for selection bias. Genome Biol 11: . doi: 10.1186/gb-2010-11-2-r14

Zhao H, Zhang H, Cui P, Ding F, Wang G, Li R, Jenks MA, Lu S, Xiong L (2014) The Putative E3 Ubiquitin Ligase ECERIFERUM9 Regulates Abscisic Acid Biosynthesis and Response during Seed Germination and Postgermination Growth in Arabidopsis1[W][OPEN]. Plant Physiol 165:1255-1268 . doi: 10.1104/pp.114.239699 


\section{Table $\mathbf{1}$ (on next page)}

Selected differentially expressed genes. 


\begin{tabular}{|c|c|c|c|c|}
\hline $\begin{array}{l}\text { Maize } \\
\text { gene }\end{array}$ & Description & $\begin{array}{l}\log _{2} \\
\text { fold- } \\
\text { change }\end{array}$ & $\begin{array}{l}\text { Upregulated } \\
\text { in: }\end{array}$ & GO category \\
\hline \multicolumn{5}{|c|}{ Regulation between $A$. gerardii and $S$. nutans } \\
\hline CB331760 & methyltransferase & 3.56 & A. gerardii & Cellular metabolic process \\
\hline DV621283 & GTP binding protein & 3.28 & A. gerardii & Cellular metabolic process \\
\hline DV490673 & $\begin{array}{l}\text { Dihydrouridine } \\
\text { synthase (Dus) }\end{array}$ & 2.99 & A. gerardii & Cellular metabolic process \\
\hline DV491165 & transcription factor & 2.60 & A. gerardii & Biological regulation \\
\hline BM331929 & transcription factor & 2.56 & A. gerardii & Biological regulation \\
\hline CD510408 & fibrillarin & 2.56 & A. gerardii & Protein metabolic processes \\
\hline DV491840 & finger protein & -2.66 & S. nutans & Negative regulation \\
\hline DV491692 & $\begin{array}{l}\text { CMP-sialic acid } \\
\text { transporter homolog }\end{array}$ & -2.64 & S. nutans & Negative regulation \\
\hline DV942581 & Proteasome & -2.37 & S. nutans & Macromolecule catabolism \\
\hline DV490558 & $\begin{array}{l}\text { 1,2-alpha- } \\
\text { mannosidase }\end{array}$ & -2.13 & S. nutans & Macromolecule catabolism \\
\hline DV493085 & $\begin{array}{l}\text { ubiquitin-conjugating } \\
\text { enzyme }\end{array}$ & -1.51 & S. nutans & Macromolecule catabolism \\
\hline \multicolumn{5}{|c|}{ Regulation within $A$. gerardii } \\
\hline CB331250 & RNA-binding protein & -1.01 & Drought & Osmotic stress \\
\hline CA989232 & ribosomal protein $\mathrm{S} 3$ & -1.51 & Drought & Osmotic stress \\
\hline BM347878 & aconitate hydratase & -1.17 & Drought & Osmotic stress \\
\hline CD651535 & $\begin{array}{l}\text { histone } \\
\text { acetyltransferase }\end{array}$ & -1.33 & Drought & Chromatin silencing \\
\hline CB815849 & $\begin{array}{l}\text { histone } \\
\text { acetyltransferase }\end{array}$ & -1.86 & Drought & Chromatin silencing \\
\hline DY576254 & Hsp70 protein & -1.06 & Heat wave & Protein folding \\
\hline CD662140 & $\begin{array}{l}\text { high mobility group- } \\
\text { box domain }\end{array}$ & 1.08 & $\begin{array}{l}\text { Ambient } \\
\text { temp. }\end{array}$ & DNA binding \\
\hline \multicolumn{5}{|c|}{ Regulation within $S$. nutans } \\
\hline DV489871 & $\begin{array}{l}\text { ERBB-3 binding } \\
\text { ribonuleoprotein }\end{array}$ & $\mathbf{1 . 3 3}$ & Watered & ncRNA metabolism \\
\hline DV489639 & $\begin{array}{l}\text { serrate RNA effector } \\
\text { molecule }\end{array}$ & 1.24 & Watered & ncRNA metabolism \\
\hline DV943322 & $\begin{array}{l}\text { pseudouridine } \\
\text { synthase }\end{array}$ & 1.16 & Watered & ncRNA metabolism \\
\hline DV942798 & $\begin{array}{l}\text { ribosome production } \\
\text { factor } 2\end{array}$ & 1.04 & Watered & ncRNA metabolism \\
\hline BM073337 & $\begin{array}{l}\text { polyribonucleotide } \\
\text { nucleotidyltransferase }\end{array}$ & 1.02 & Watered & ncRNA metabolism \\
\hline CD651136 & $\begin{array}{l}\text { Cysteinyl-tRNA } \\
\text { synthetase }\end{array}$ & 2.14 & Watered & ncRNA metabolism \\
\hline
\end{tabular}




\begin{tabular}{|c|c|c|c|c|}
\hline BM078961 & $\begin{array}{l}\text { methionine-tRNA } \\
\text { ligase }\end{array}$ & 1.26 & Watered & ncRNA metabolism \\
\hline CD651793 & $\begin{array}{l}\text { valine-tRNA ligase } \\
\text { with editing activity }\end{array}$ & 1.24 & Watered & ncRNA metabolism \\
\hline DV492155 & aquaporin NIP3-1 & 1.22 & Watered & Transmembrane activity \\
\hline BM340348 & $\begin{array}{l}\text { NEP1-interacting } \\
\text { protein }\end{array}$ & 1.19 & Watered & Methyltransferase activity \\
\hline DV492743 & $\begin{array}{l}\text { transcriptional } \\
\text { corepressor }\end{array}$ & 1.17 & Watered & $\begin{array}{l}\text { Negative regulation of } \\
\text { transcription }\end{array}$ \\
\hline CD527890 & $\begin{array}{l}\text { E3 ubiquitin ligase } \\
\text { SUD1 }\end{array}$ & -2.24 & Drought & Osmotic stress \\
\hline DV489949 & aldo-keto reductase & -2.16 & Drought & Osmotic stress \\
\hline BM348293 & $\begin{array}{l}\text { hydrophobic protein } \\
\text { LTI6A }\end{array}$ & -1.01 & Drought & Osmotic stress \\
\hline DV491692 & $\begin{array}{l}\text { CMP-sialic acid } \\
\text { transporter homolog }\end{array}$ & -2.35 & Drought & Encapsulating structures \\
\hline DV492287 & $\begin{array}{l}\text { phosphatidylinositol } \\
\text { kinase }\end{array}$ & -2.12 & Drought & Encapsulating structures \\
\hline BM333861 & $\begin{array}{l}\text { pectin acetylesterase } \\
8\end{array}$ & -1.65 & Drought & Encapsulating structures \\
\hline DV491662 & $26 \mathrm{~S}$ protease & -2.40 & Drought & Catabolism \\
\hline DV492129 & $\begin{array}{l}\text { DNA-directed RNA } \\
\text { polymerase II Rpb7p }\end{array}$ & -2.35 & Drought & Catabolism \\
\hline DV492287 & $\begin{array}{l}\text { phosphatidylinositol } \\
\text { kinase }\end{array}$ & -2.12 & Drought & Catabolism \\
\hline DV942393 & $\begin{array}{l}\text { GDP-mannose 4,6 } \\
\text { dehydratase }\end{array}$ & -4.99 & Drought & Organophosphate metab. \\
\hline DV493244 & $\begin{array}{l}\text { triosephosphate } \\
\text { isomerase }\end{array}$ & -2.47 & Drought & Organophosphate metab. \\
\hline DV491451 & $\begin{array}{l}\text { phosphatidylinositol- } \\
\text { 4-phosphate 5-kinase }\end{array}$ & -2.10 & Drought & Organophosphate metab. \\
\hline
\end{tabular}


Figure 1 (on next page)

Differentially expressed genes in A. gerardii and S. nutans.

Differentially expressed genes have a $\log _{2}$ fold change greater than one, shown as colored points where $p<0.05$. Positive values indicate greater expression in $A$. gerardii while negative values indicate greater expression in $S$. nutans. Filled circles represent genes belonging to selected Gene Ontology groups. Open circles: red $=$ differentially expressed, gray $=$ not significantly different 


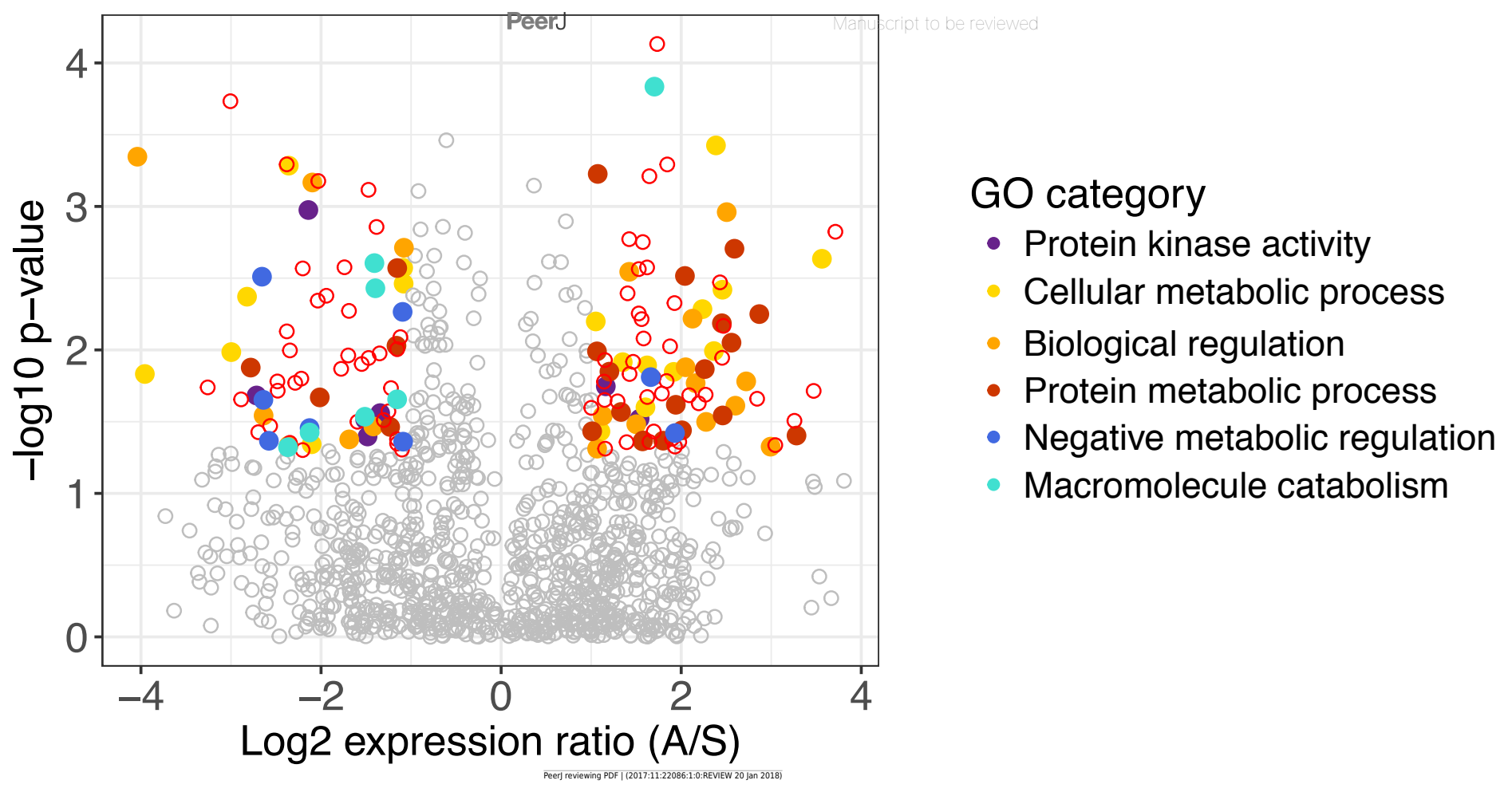




\section{Figure 2 (on next page)}

Gene modules explaining species differences under different water availability.

Gene modules detected explaining species differences in watered $(A)$ and drought $(B, C)$ conditions. Sample names are presented on the x-axis, where each label applies to two columns of the same description (e.g. Ag.W.H applies to the first two columns, but both are replicates of $A$. gerardii in Watered plot with Heated treatment). $\mathrm{Ag}=A$. gerardii, $\mathrm{Sn}=\mathrm{S}$. nutans, $\mathrm{W}=$ watered, $\mathrm{D}=$ drought, $\mathrm{H}=$ heated $\mathrm{A}=$ ambient temperature. No annotation found $=$ N.A. 
2 Vacuolaj protein sorting Protein STRUBBELGG-RECEPTOR Pseudouridine synthase Transcription factor ILR3 N.A.

RNA polymerase II associated protein 2 Serine Threonine protein kinase Serine Threonine protein kinase Protein SAWADEE HOMEODOMAIN Heptahelical transmembrane protein Ribosome production factor 2

Tubulin gamma-2 chain Tubulin alpha-3 chain 2OG-Fe(II) oxygenase 1,2-alpha-mannosidase MNS1 26S proteasome

Thymidylate synthase

Protein transport protein Sec24 Folate biopterin transporter Phosphatidylinositol 4-kinase

Glucuronosyltransferase N.A. N.A.

$\mathrm{CBL}$-interacting protein kinase Histone $\mathrm{H} 2 \mathrm{~B} .1$

Transcription factor BTF3 Splicing factor (U2AF) Ribophorin II

$50 S$ ribosomal protein $L 20$

Katanin p60 ATPase-containing subunit A1 N.A.

Transcriptional corepressor N.A.

Two-component response regulator OR.A. N.A

DNA-directed RNA Polymerase U6 snRNA-associated Sm-like protein PHD finger protein Alfin1 Ubiquitin-conjugating enzyme Ammecr1 domain-containing protein

Pyridoxal reductase, chloroplastic Pseudouridylate synthase 7

Copper methylamine oxidase Cullin-1

SNF1-related protein kinase Golgi intermediate compartment protein 3 Calcium-binding protein Aspartic proteinase

Calcineurin B-like protein 3

Alpha-N-acetylglucosaminidase Putative hydrolase Valine--tRNA ligase

Poly(A) polymerase

Eukaryotic translation initiation factor $6-2$ Golgi intermediate compartment protein Methionine--tRNA ligase Outer envelope pore protein 16-1, chloroplastic Proteasome subunit alpha type-7-A b)

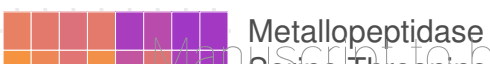

Metallopeptidase

serine tinrebpine arotem/kinased

Histone H2B.2

2OG-Fe(II) oxygenase

N.A.

Actin

Eukaryotic translation initiation factor

N.A.

Squamosa promoter-binding-like protein

N.A.

Guanine nucleotide-binding protein

Thymidylate synthase

N.A.

HAD-hyrolase-like

Proliferating cell nuclear antigen

$40 S$ ribosomal protein $\mathrm{S} 18$

Hexokinase-3

Auxin-responsive protein

N.A.

Zinc ion binding

Copper-transporting ATPase

Zinc transporter ZTP29
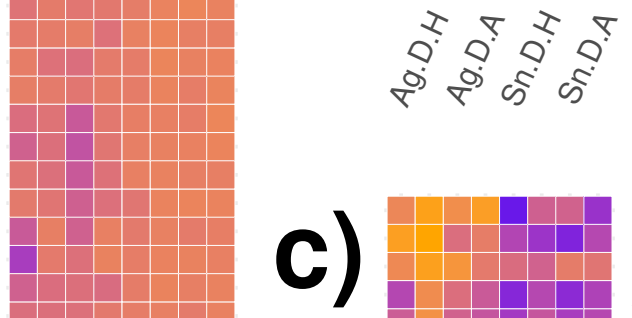

Cell division control protein

Heat shock $70 \mathrm{kDa}$ protein

Protein phosphatase 2

Arginosuccinate synthase

GDP-mannose 3,5-epimerase

Serine Threonine protein kinase

Malate dehydrogenase

DAHP synthetase I family

Serine Threonine protein kinase

Sirohydrochlorin ferrochelatase

Casein kinase II subunit beta-3

Transcriptional corepressor

N.A.

N.A.

Coatomer protein complex

Transmembrane 9 superfamily member 9

$60 S$ ribosomal protein L10

Pyridoxal reductase

Cullin-1

Chaperone protein dnaJ 13

Glycerophosphodiester phosphodiesterase GDPD5

N.A.

snoRNA binding domain, fibrillarin

Tubulin-folding cofactor A

Bax inhibitor 1

SKP1-like protein 1B

Transcription factor TFIID

Disease resistance RPP8-like protein

methionine--tRNA ligase

N.A.

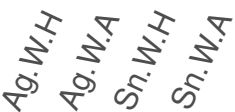

20

के के के 


\section{Figure 3 (on next page)}

Differentially expressed genes in response to water availability.

Differentially expressed genes in a) $A$. gerardii and b) S. nutans only compared between watered and drought plots (12 and 13). Significantly different genes with $\log _{2}$ fold change greater than one are represented by colored points where $p<0.05$. Positive values indicate greater expression in the watered plot while negative values indicate greater expression in the drought plot. Filled circles represent genes belonging to selected Gene Ontology groups. Open circles: red = differentially expressed, gray = not significantly different. 


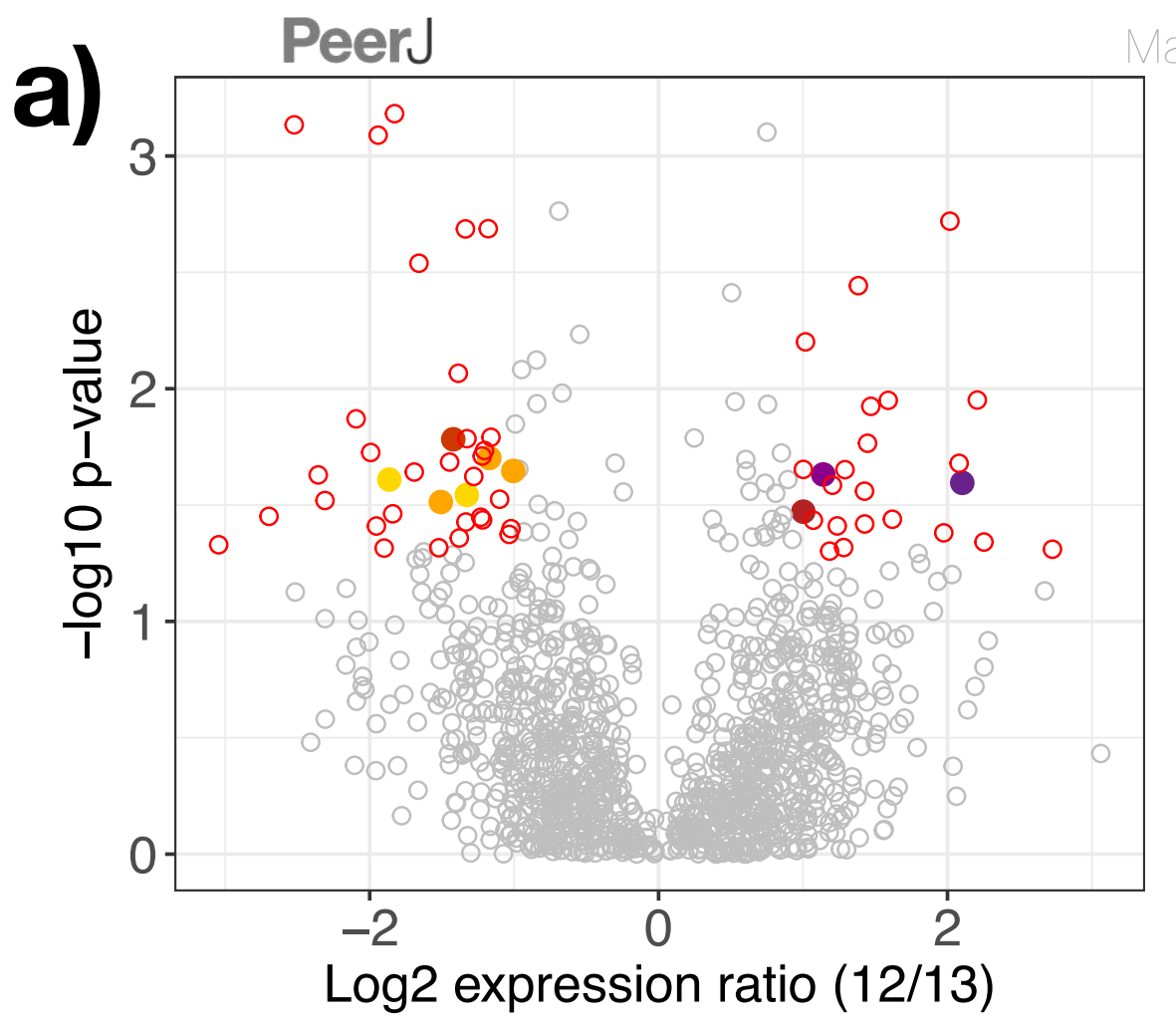

\section{GO category}

- Ion transport

- Sucrose biosynthesis

- Xylose metabolism

- Chromatin silencing

- Response to osmotic stress

- Lysosome

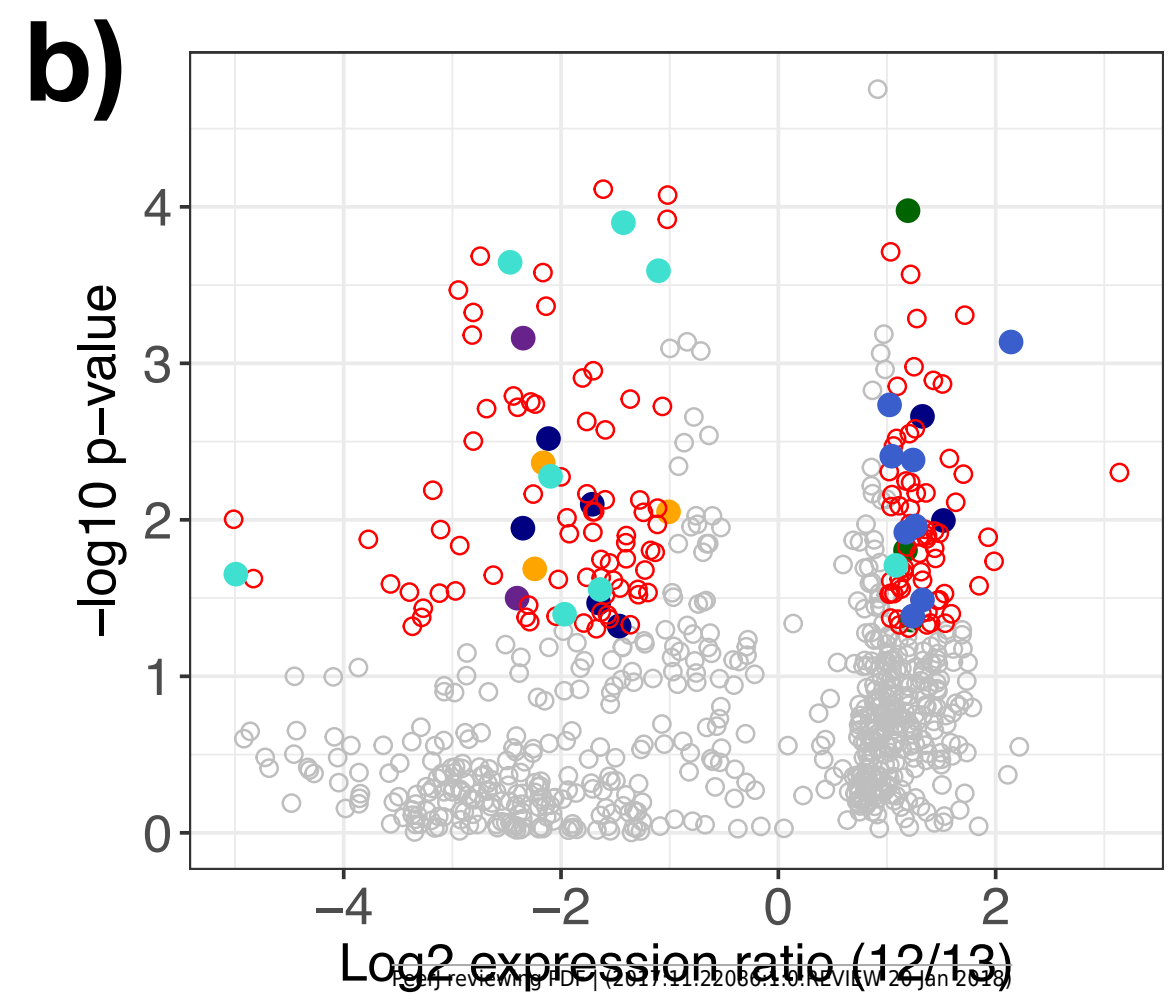

\section{GO category}

- Nitrogen response

- Cellular catabolism

- External encapsulating structure

- Response to water stress

- ncRNA metabolism

- Organophosphate metabolism 